\title{
Video games, parental mediation and gender socialization
}

\author{
Ana Aierbe \\ ana.aierbe@ehu.eus \\ University of the Basque Country (UPV/EHU), Spain \\ Eider Oregui \\ eider.oregui@ehu.eus \\ University of the Basque Country (UPV/EHU), Spain \\ Isabel Bartau \\ isabel.bartau@ehu.eus \\ University of the Basque Country (UPV/EHU)
}

\begin{abstract}
The study examines the parental perception of the use of video games by their preadolescent children, as well as parental beliefs, mediation practices and difficulties they encounter. In total, 186 parents have participated. The results, gathered in the quantitative and qualitative phase, reveal differences in parental perception according to the age and sex of their children; parents have more negative than positive beliefs about video games and use more strategies based on control than on support and communication. In parents' opinion, the difficulties for mediation are related to the precocity to which they access the media and Internet, social pressure, uncontrollability and the digital divide. The paper concludes with implications for the educational intervention aimed to respond to parents' concerns and needs for information and training.
\end{abstract}

\section{Keywords}

Video Games, Parental Mediation, Parental Beliefs, Early Adolescence, Gender 


\section{Introduction}

Among the younger generations, interactive technologies are triggering changes in social relations, in the manner in which people access knowledge, in how they process information and even in the way they think. The vertiginous pace at which the media and their use in the family environment have progressed has created a digital divide between adults and adolescents (Sarabia \& Muñoz, 2009; Wartella \& Jennings, 2001), with children becoming experts while many parents lack even the most rudimentary knowledge. The same is true of video games, and although many parents today are themselves avid players, this does not mean they do not encounter difficulties when attempting to share and mediate their use (Oosting, IJsselsteijn \& de Kort, 2008).

According to the studies reviewed in the Spanish context (AEVI, 2015; Lloret, Cabrera \& Sanz, 2013), video games are very common and popular among young people and the intensity with which they are played has aroused concerns regarding their possible effects on players' cognitive and social development. Moreover, the growing trend towards accessing contents and games on portable devices and the increasingly young age at which children first begin accessing the Internet has forced parents to adapt their supervision and mediation techniques to these new habits. Consequently, this study chose the transitional period between childhood and adolescence to analyze the use of video games and parental mediation practices.

Analyses of video gaming habits among the younger generations have found that video games are played most by adolescents and males. Studies focusing on children also observed that boys played more often than girls. In relation to age, as children grow older they tend to play less (AEVI, 2015; Reig \& Vilchez, 2013).

Most gamers play alone, although some do so with friends and/or siblings, and a smaller number play with their parents (Bourgonjon, Valcke, Soetaert, Wever \& Schellens, 2011). This has been interpreted as an indication that more direct personal relationships may be being substituted by remote, technologically-mediated ones (Reig \& Vilchez, 2013). Moreover, Punamäki, Wallenius, Hölttö, Nygard \& Rimpelä (2009) found that time spent playing on-line video games was related to poorer social and family relations.

In relation to the themes of video games, children prefer adventure, sports, fighting and strategy games over simulation, role play, platform or other types of game (Cánovas, 2005). In general, boys are more interested in action while girls tend to prefer adventure games to combat ones (Zhao \& Linaza, 2015). Likewise, Bertomeu (2011) points out that, according to sales figures, simulation games are the most popular among adolescent girls, alongside games which reproduce traditional female roles (being a nurse, etc.). Furthermore, games in which the lead characters are females tend to adopt violent masculine models charged with eroticism.

\section{a. Parental mediation}

How do parents regulate their children's video gaming? It should be remembered that children start playing video games at a very early age, during a stage in which they are fully immersed in their socialization process, in which in addition to the family, school, friends and the media all have a role to play. Of these agents, the family is the most important due to its key role in helping children acquire 
new behaviors and form and develop attitudes. Therefore, parental control plays a decisive role in the regulation of play-related behavior (DeCamp \& Ferguson, 2017; Lloret et al., 2013), even though in the age range studied here, namely the transition from childhood to adolescence (8-9 and 11-12), the peer group gradually becomes more and more important for socialization and personal development.

Parental mediation is defined as the degree and manner in which parents intervene in the relationship their children establish with the media. As regards the management of their children's video game playing, some authors (Martins, Matthews \& Ratan, 2015; Shin \& Huh, 2011) propose three mediation styles: a) active or instructive, which consists of fostering communication and dealing with aspects relevant to the content; b) restrictive, which is based on establishing rules that restrict media use, including time and content restrictions; and c) co-playing or shared playing, which consists of participating in the experience, but without making any comments regarding its content or effects.

Some quantitative and qualitative research in the field of electronic-media, communication and family studies try to describe interaction and parental mediation around the use of media (Clark, 2011; Kutner, Olson, Warner \& Hertzog, 2008; Sheffield, 2014; Shin \& Huh 2011; Wartella \& Jennings, 2001; Zaman, Nouwen, Vanattenhoven, de Ferrerre \& Van Looy, 2016). From this framework Clark (2011) suggest, in addition to active, restrictive, and co-use as parental mediation styles, to consider another one, participatory learning, that involves parents and children interacting together with and through digital media.

Recently, Zaman et al. (2016), in addition to defending the concept of participatory learning (Clark, 2011), point to another parenting strategy called distant mediation, which aggregates two previously defined monitoring practices, namely deference and supervision, since some parents monitor adolescents' behavior while deliberately granting them trust and autonomy. In this sense, the authors point to the varied nuances of monitoring children's and adolescent's media use and suggest the existence of a less hierarchical role for the parent, who is no longer expected to always take the lead. On the other hand, there is general agreement among researchers that parental strategies for mediating children's video game playing tend mainly to consist of restrictive measures. In other words, parents tend to restrict access rather than propose rules, share in the experience (co-play) or talk about the games (Bourgonjon et al., 2011; Kutner et al., 2008; Nikken \& Jansz, 2006).

Upon analyzing the strategies used by parents of children and adolescents aged between 8 and 18 to regulate their video gaming, in a sample of 536 parent-child pairs, Nikken \& Jansz (2006) found that participation or mediation styles used tending to be related to parents' knowledge of the different media in question. Thus, the more parents are concerned about the negative effects of video games on their children's behaviors and attitudes, the more restrictive and evaluatory-instructive their mediation style, and inversely, parents who are convinced of the positive social-emotional effects of video games tend to engage in co-playing more frequently. For their part, children believe that arguments with their parents about video games tend to be due to (in order of frequently, from most to least frequent) the amount of time they spend playing, the time of day they play and the type of games they play (Cánovas, 2005).

Nevertheless, new trends indicate that all screen types are converging, and all are starting to offer Internet access. Consequently, new concerns are arising among parents which transcend the classic issues of controlling content, use and time. This was the reason that prompted us to explore, using 
both quantitative and qualitative techniques, how parents mediate their children's video game playing and what difficulties they experience when doing so.

Parental control has a decisive influence on time spent playing and the type of game played. Nevertheless, this control is not always exerted, and even when it is, it is often inconsistent. Some studies report that parents hardly ever participate in their children's games (aDeSe, 2009; Lenhart et al., 2008). However, according to a report published by the Spanish Video Game Association (AEVI, 2015), parents' involvement has increased as they themselves have begun to play, with $36.2 \%$ of parents playing video games with their children. For the most part, it is parents under the age of 30 who tend to play video games most often with their children.

Coyne, Padilla-Walker, Stockdale \& Day (2011) point out that the greater or lesser degree of coplaying between parents and children has implications for the family that should not be underestimated. While long periods of individual use are associated with certain negative consequences such as aggressive behavior and a lower level of prosocial behavior, co-playing is related to lower levels of aggressive behavior and higher scores for prosocial behavior, at least among girls.

Parental beliefs (both positive and negative) about video games have also been studied, with belief being taken to mean the knowledge or information that parents assume to be true (Schafer \& Tait, 1981). Parents' beliefs about information technology have been studied almost exclusively in relation to mediation, using questionnaires rather than qualitative techniques. Attempts have also been made to identify how parenting styles and rules impact media use by children and adolescents.

In addition to recognizing that video games may have positive effects (i.e. improving cognitive skills), parents also express concern regarding (a) the balance struck between playing video games and engaging in other activities, (b) the video game environment, (c) their possible harmful effects, and (d) mediation strategies (Kutner et al., 2008).

In the opinion of Oosting et al. (2008), one of the principal factors contributing to parents' concerns over the negative effects of video games on their children is all the attention paid by the media to the potentially harmful effects of these games (e.g. increase in obesity or childhood violence).

When examining the difficulties encountered by parents when attempting to mediate their children's video gaming, it is important to bear in mind the effect of the digital divide which exists between generations. As a result of this divide, parents need to make a greater effort to learn about and mediate their children's use of screens (Sarabia \& Muñoz, 2009). Despite the fact that many parents today play video games themselves, the high-tech nature of the games and the diversity of their content makes it hard even for these parents to understand and effectively guide their children through the different options and types of media use available (Oosting et al., 2008). Moreover, the dominant trend today is Internet-enabled multi-screen use on small, portable devices, such as consoles and mobile phones (Livingstone, Marsh, Plowman, Ottovordemgentschenfelde \& FletcherWatson, 2014), from which children and adolescents access on-line games to play with their friends and/or strangers, something which makes parental mediation even more difficult. To this end, this study examines the similarities and differences in parental mediation of children's video game playing during the transition from childhood to adolescence. Taking into account the considerations outlined above, the key questions which this study aims to answer are as follows: RQ1: Do parents' perceptions of their child's use of video games differ in accordance with the sex of that child?, RQ2: What are 
parental beliefs about video games?, RQ3: What mediation strategies (instructive (support and communication), co-playing (shared playing) and restrictive (time and content control)) do parents use? RQ4: What difficulties do they perceive in relation to regulating their children's use of video games?

\section{Methods}

This study forms part of a broader research project on primary school children's media diet, socialpersonal development and parental mediation. The project is divided into two phases, a quantitative one consisting of a questionnaire and a qualitative one which uses the discussion group technique. The aim of this study is not to generalize the results obtained, but rather gather information about and respond to schools' and parents' concerns and demands for information and training on the media diet of children in this developmental stage.

\section{a. Participants}

186 parents participated in the first phase of the study (20.4\% fathers and $79.6 \%$ mothers). Of their children, 92 were boys and 94 girls; of these, 39.2\% were aged between 8-9 and were in 3rd grade of primary school ( $57.5 \%$ boys and $42.5 \%$ girls), and $60.8 \%$ were aged between $12-13$ and were in 6 th grade $(44.2 \%$ boys and $55.8 \%$ girls). Students were recruited from four schools in the north region of Spain (two public schools and two semi-private ones, i.e. private schools that receive some state funding). $57.24 \%$ of parents had a high educational level, $21.38 \%$ a medium level and $21.38 \%$ a low level. As regards their professional level, $39.72 \%$ had a high level, $31.91 \%$ had a medium level and $28.37 \%$ a low level.

During the second phase of the study, 44 of the original 186 parents participated voluntarily in four discussion groups (NG1=10, NG2=8, NG3=15 and NG4=11). Of these 44 parents, 37 were mothers and 7 were fathers; 18 had sons and 26 had daughters; and 16 had a child in 3rd grade and 28 had a child in 6th grade.

\section{b. Measures}

The instrument used to obtain information during the first phase of the study was the parents' version of the Children's Media Diet Questionnaire (CMI; Aierbe \& Oregui, 2016), which comprises 26 items to be completed in an estimated 30 minutes. The following dimensions and variables were analyzed in this study:

\section{Use of video games}

This dimension includes hours spent playing on weekdays and at weekends (items 1 and 2), habitual use of screens in the bedroom (item 3), leisure activities (item 5), use of video game consoles with or without Internet access (item 19), type of video game console owned (item 20), preferred type of video game (item 21: action/war, sport, car-motorbike races, adventure, others), favorite video game (item 22), social context in which they play (item 23: alone at home, with parents, with friends, at home with their friends, on-line with their friends and/or strangers), general purpose (item 25: 
information-training, entertainment or leisure, communication-socialization, purchases-downloading and/or renting), and specific purpose (item 26).

\section{Parental mediation strategies and styles in relation to video gaming}

As shown in Table 1, the parental mediation styles and strategies in relation to video gaming were divided into three dimensions: instructive (support and communication), co-playing (shared playing) and restrictive (time and content control).

Parental mediation styles and strategies

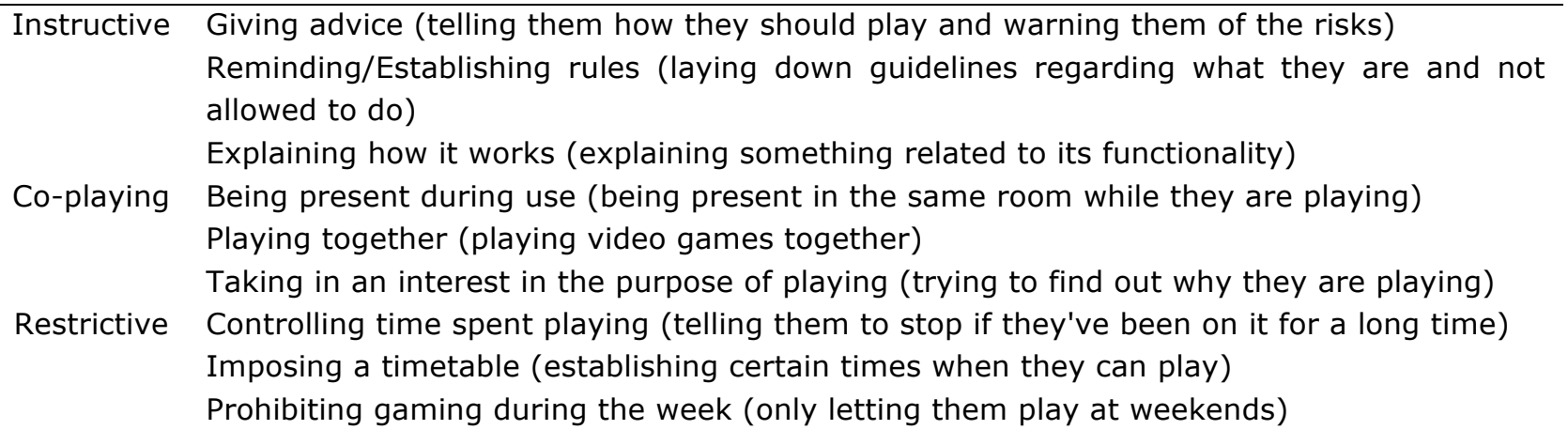

Table. 1. Parental mediation styles and strategies in relation to video gaming as reported in the Children's Media Diet Questionnaire or CMI

Source: Aierbe \& Oregui, 2016

During the second phase of the study, four discussion groups were organized with the aim of reflecting on and discussing children's media diet (television, computers, video games, mobile phones, tablets and the Internet) and parents' role in regulating it. The questions posed to participants were: 1) What positive and negative effects do you believe media use has on children? 2) How do you usually act in relation to your child's media diet? and 3 ) What difficulties do you usually encounter? In this study, we present the results for video games.

The study also bore in mind a number of other variables such as parents' sex and children's sex, school year and age (3rd grade/8-9 years old or 6th grade/12-13 years old).

\section{c. Procedures}

The collaboration of the management teams and parents' associations of four schools was requested in order to ensure the participation of parents and students. Parents were then sent a letter explaining the aims of the research project and, after gaining their informed consent, students were sent home with the CMI questionnaire for their parents to complete within the space of a week. The completed questionnaires were returned to the schools by the students. The instructions provided included a request that just one parent fill in the questionnaire, and that that parent be the one most familiar with the child's habits in relation to video games and other screen-based media at home. Parents were also invited to participate in a discussion group session lasting approximately 90 minutes. The sessions were recorded (audio only, not video) and later transcribed. 
The quantitative analysis of the data was carried out using the SPSS Statistics 24 program. The Kolmogorov-Smirnov test revealed that the data had a non-normal distribution. Subsequently, descriptive analyses (frequencies, means, standard deviations) were conducted, along with means comparisons using the non-parametric Mann-Whitney and Kruskal-Wallis tests. The information gathered in the discussion groups was analyzed using the qualitative data analysis program NVivo10. The procedure consisted of the classification, analysis and synthesis of the categories.

\section{Results}

\section{a. Parents' perceptions}

This section outlines the results obtained in relation to time spent playing, the physical and social context of play, type of support, type of games played and children's favorite games.

Of the 186 parents, $82.8 \%$ said their children never play video games during the week, and $11.3 \%$ said they spend 1 hour or less a day playing video games on weekdays. At weekends use increases, with $67.2 \%$ saying they play video games for less than an hour a day, $16.7 \%$ saying they do so for an hour, $10.8 \%$ saying they play for two hours and $5.6 \%$ saying their children spend three or more hours a day playing video games.

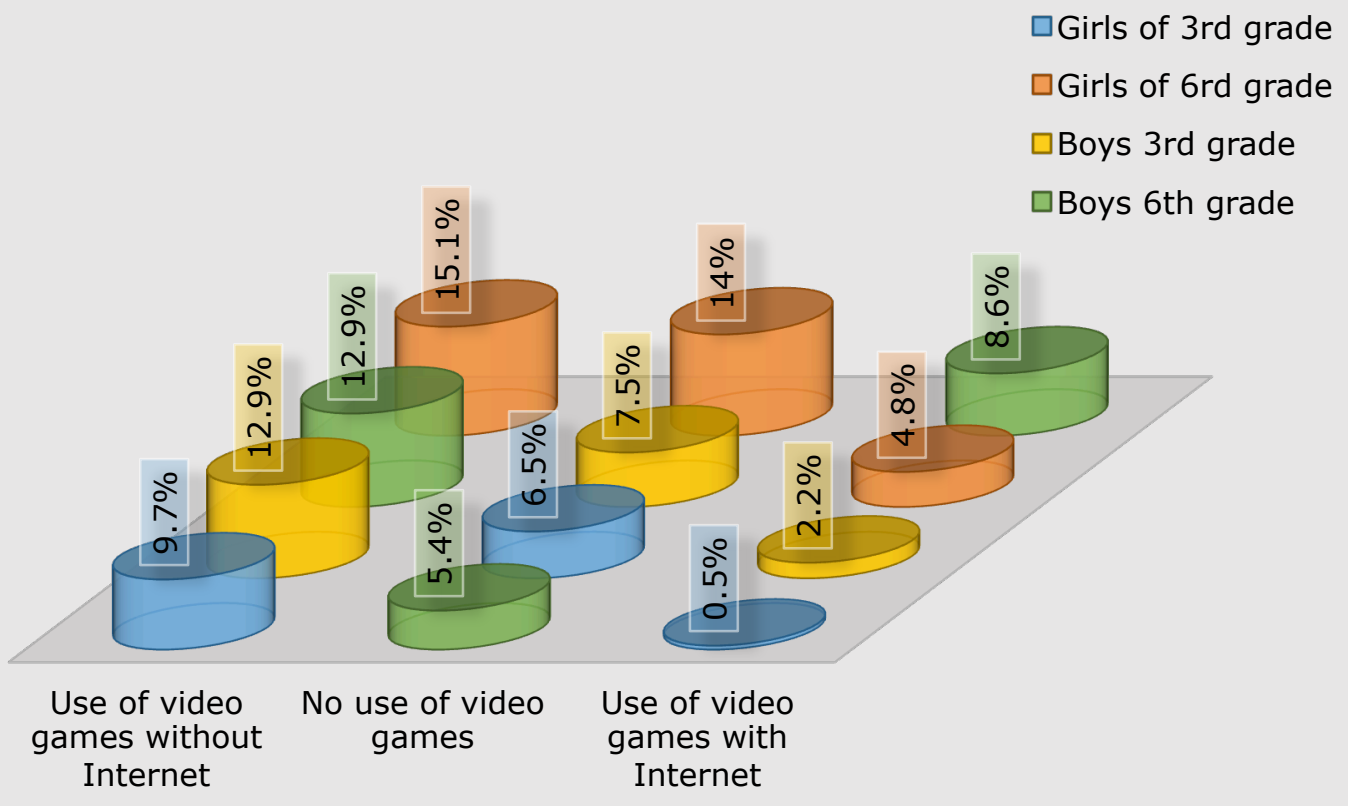

Figure. 1. Use of video games

Source: Oregui, 2018, p.129

Age and sex differences were observed in relation to video gaming (see Figure 1). Half of the participants (50.5\%) said their children played video games without Internet access, $16.1 \%$ said they played with Internet access and $14.5 \%$ said they never played at all. As for age, 6 th grade students tend to connect up to the Internet more than 3 rd year ones $(22.1 \%$ and $6.8 \%$, respectively) in order 
to play video games with their friends $(Z=-3.008 ; p<.01 ; 1.20$ vs .73$)$ and/or with strangers $(Z=-$ $2.757 ; p<.01 ; 1.03$ vs .68). Boys tend to play video games in their spare time more than girls $(Z=-$ $3.120 ; p<.01 ; 2.16$ vs 1.46$)$, and spend more time playing both during the week $(Z=-3.587 ; p<$ $.001 ; .46$ vs .10) and at weekends $(Z=-4.424 ; p<.001 ; .99$ vs .24$)$. Moreover, boys also tend to connect up to the Internet more than girls when playing ( $21.7 \%$ vs $10.6 \%)$.

Children's favorite types of video game, in order from most to least popular, are: adventure (17.25\%); sport (15.75\%); and action/war (5.25\%). Curiously enough, the others category (mentioned more often by girls) came joint second with sport, with $16.5 \%$ of responses referring to video games involving caring for pets, dance and singing games and/or sewing, fashion or makeup games.

When the data is broken down according to age group, we see that 6th graders tend to play more action/war games $(Z=-2.119 ; p<.05 ; 1.39$ vs .99) and those classified as others $(Z=-2.076 ; p<$ $.05 ; 1.98$ vs 1.45$)$ than 3rd graders.

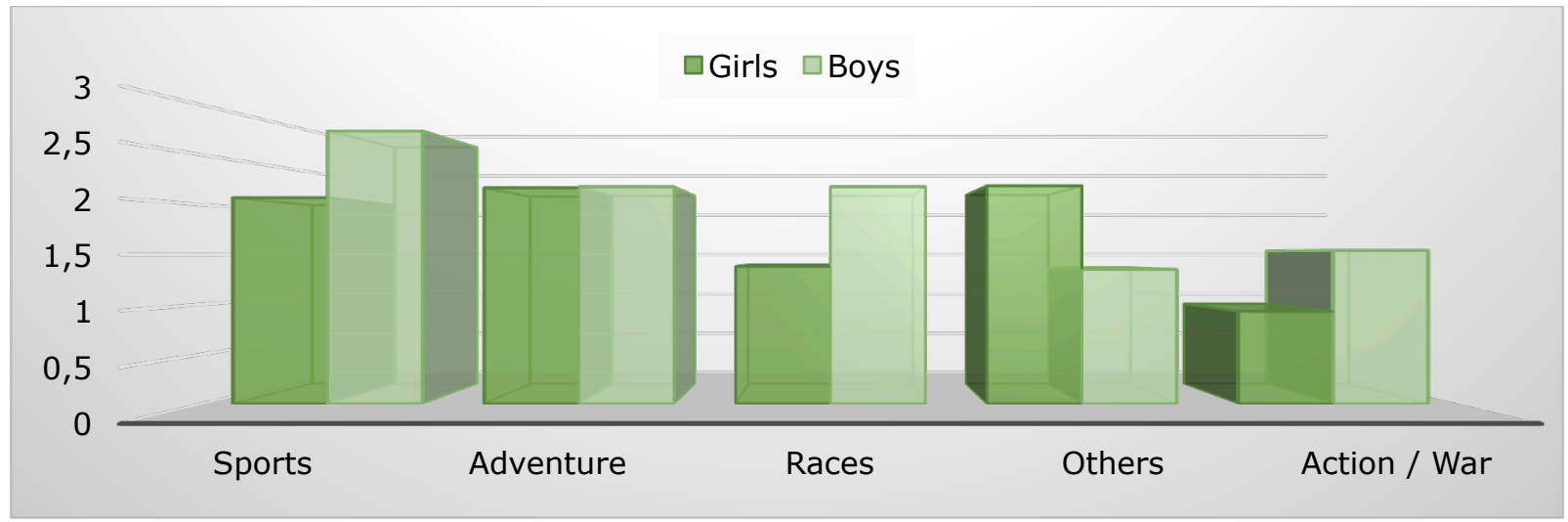

Figure. 2. Types of video games

As regards sex (see Figure 2), boys play more sports $(Z=-2.767 ; p<.01 ; 2.74$ vs 2.07), car/motorbike racing $(Z=-3.141 ; p<.01 ; 2.18$ vs 1.38$)$ and/or action/war games than girls $(Z=-$ $2.387 ; p<.05 ; 1.54$ vs .93); while girls tend to prefer other types of games $(Z=-3.436 ; p<.001$; 2.19 vs 1.35$)$, as mentioned above.

\section{b. Parents' beliefs}

The group discussions elicited both positive and negative perceptions of children's video gaming (see Table 2), and well as some gender stereotypes. Comments were recorded on the enormous power of attraction that screens have over children from a very early age, as well as on the environmental pressure that encourages their use and the importance of parental attitudes to the media, due to the influence these attitudes have on how their children use them. For example:

You know, they believe that they (i.e. screens) are the doorway to infinity, that they open the door to ... who knows where. They are aware that there is something behind it. This is especially true with mobile phones, at least in my case. Now my eldest (3rd grade of primary) has a Nintendo, because all her cousins have one. The environment has an enormous influence. 'If everyone else has one, why can't I?' I also think our attitudes have a lot of influence. 


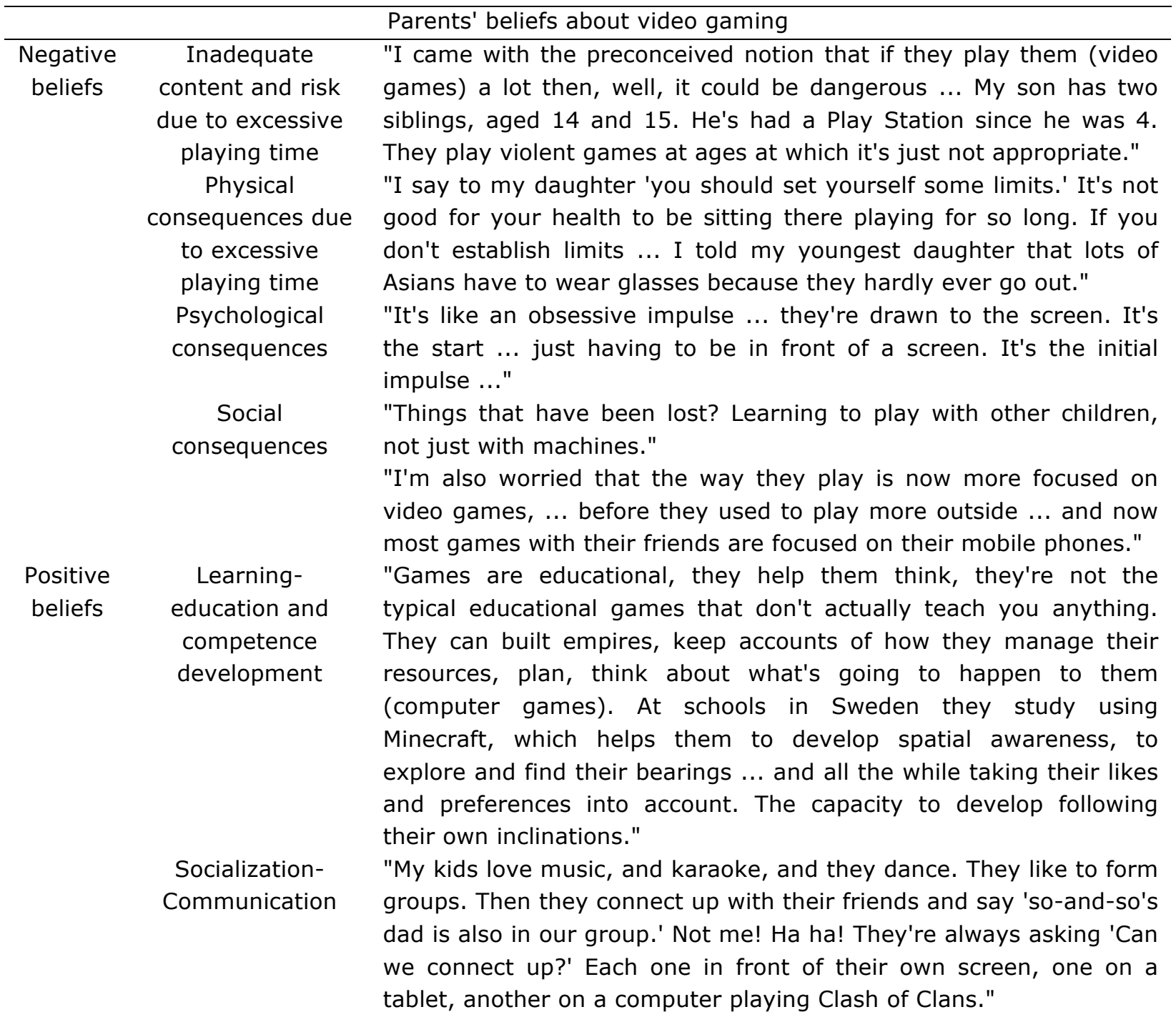

Table. 2. Parents' negative and positive beliefs regarding their children's video gaming

They also consider the (simultaneous) use of different media in different contexts of everyday life as inevitable in today's multi-screen society, although they allude to the widespread belief regarding the harm that screen use may do to children if they start too early. They also recognize that the digital culture is the culture of the younger generations. For example:

He (my son) sees the Nintendo as something pertaining to the last century. They each have their own tablet, mobile phone, etc. even the one in 3rd grade (of primary). It's often frowned upon, but I think it's inevitable, it's the sign of the times. My husband and I each have our own tablet in front of us while we watch TV. And at the office we all sit in front of computers all day, and we all have our mobiles beside us, WhatsApping with our mothers, or colleagues. These kids are living in a different environment from ours. 
The negative beliefs stated by parents regarding video games were classified into three categories: inappropriateness, risks and consequences. In specific terms, they highlight the possible risks and negative consequences (psychological and physical) resulting from excessive playing time and the ageinappropriate content (e.g. violence). This last factor is often associated with lack of control over the situation, or in other words, since older siblings, relatives or friends have video games that are inappropriate, it is easier for younger children to access them and more difficult for parents to regulate their use. Nevertheless, one comment was recorded which contradicted this and which relativized the risk of addiction and minimized the effects of video games in relation to other media such as mobile phones and the Internet. "More than addition to possible games, which can be controlled relatively easily, we are concerned about the photos and videos, etc. that they take/record of each other. We are concerned about how they are recorded and how they are used."

For their part parents' positive beliefs were grouped into the following categories: access to information, learning-educating, children's development and socialization-communication. Firstly, parents recognize and praise the usefulness of video games as a source of knowledge and teachinglearning. Moreover, one positive aspect that parents particularly stress is the use of video games as a means of socializing-communicating, since through them, children participate in groups and communicate with their friends.

However, the parents participating in the group discussion did spontaneously evince certain gender stereotypes, especially when talking about the choices made by their sons or daughters. For example "(Clash of Clans) That's totally a boys' game. He's been playing it now for seven years. I am incapable of understanding it. They can play it on any device"; and another parent states "Girls don't play Clash of Clans, in my example I'm talking about two boys. It's not violent. The violent one is Call of Duty."

In some cases, parents associate violent games with boys, while dismissing their importance for girls:

But the innocent ones, right? Games, dancing ... for the moment anyway. And I think ... look, I've got two girls and I don't think they'd ever play violent games or stuff like that.

Mine might, because she has a lot of friends out there who might, and they use each other's tablets and start with the war games, and what have you. So now she's asking for them.

\section{c. Parental mediation}

According to the data collected in the questionnaire, the parental mediation styles used are as follows, from highest to lowest scoring: restrictive $(M=2.53 ;$ S.D. $=2.01)$, instructive $(M=2.35 ;$ S.D. $=$ $1.88)$ and co-playing $(M=2.25 ; S . D .=1.72)$. Almost half of all parents $(47.28 \%)$ use the restrictive style, $18.6 \%$ the instructive style and $11.62 \%$ engage in co-playing. $20.93 \%$ of parents use a mixed or combined style. Parents of 6 th graders tend to restrict their sons' use more than their daughters' $(Z=$ $-2.436 ; p<.05 ; 3.08$ vs 2.10$)$ and co-play with their male children more than with their female ones $(Z=-2.111 ; p<.05 ; 2.64$ vs 1.91$)$. 


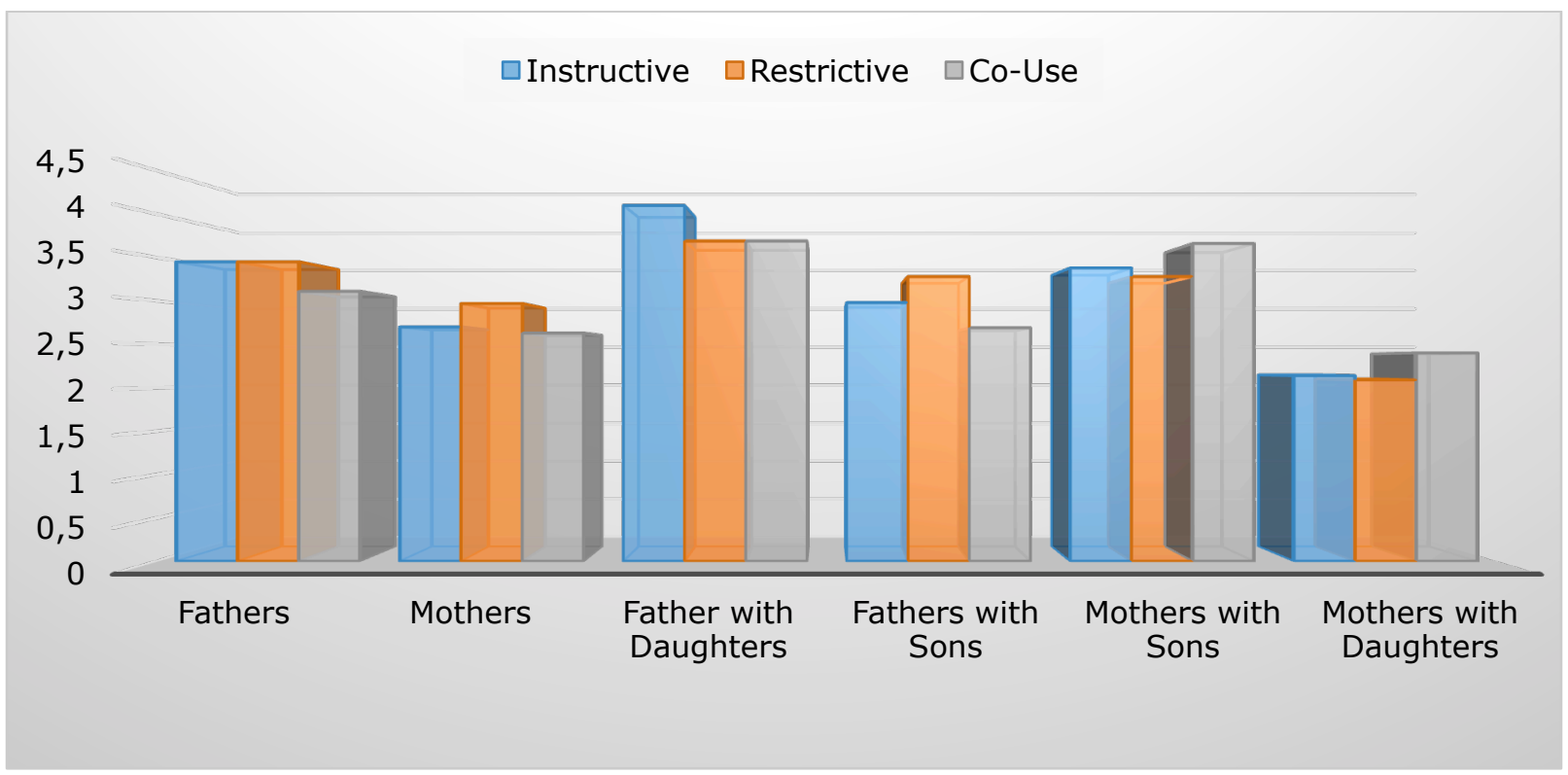

Figure. 3. Parental mediation styles

The comparison of parental mediation styles gave interesting results (see Figure 3 ), since in accordance with the scores obtained, fathers tend to use the instructive style more than mothers ( $Z=$ $-2.015 ; p<.05 ; 3.45$ vs 2.70$)$ when mediating their children's video game playing. Moreover, the results also revealed that fathers with daughters instruct their offspring $(Z=-2.277 ; p<.05 ; 4.10$ vs $2.98)$ and play video games with them $(Z=-2.302 ; p<.05 ; 3.69$ vs 2.68$)$ more than fathers with sons. For their part, mothers with sons restrict $(Z=-3.308 ; p<.001 ; 3.66$ vs 2.39$)$, instruct $(Z=-$ $3.356 ; p<.001 ; 3.38$ vs .2 .14$)$ and co-play with their offspring more than mothers with daughters $(Z$ $=-3.874 ; p<.001 ; 3.28$ vs 2.08$)$.

Of the mediation strategies used by parents, the highest mean $(M=2.79 ;$ S.D. $=2.224)$ corresponds to controlling playing time ("I tell them to stop if they've been on it for a long time") and the lowest mean $(M=1.70 ; S . D .=1.502)$ corresponds to co-playing ("I sit down and play video games with them").

No significant differences were found between the mediation strategies used in accordance with children's age. However, parents (both mothers and fathers) do tend to impose time restrictions more on sons than on daughters as a means of mediating video gaming $(Z=-2.111 ; p<.05 ; 2.93$ vs $2.21)$. Fathers tend to explain different aspects related to the functionality of the games or consoles more to their sons than mothers do $(Z=-2.469 ; p<.05 ; 3.10$ vs 2.26$)$.

As regards the data collected during the qualitative phase, parental strategies for mediating their children's use of video games were divided into two main groups: Restrictive or control strategies and instructive or support-guidance strategies.

As shown in Table 3, Control-type parental strategies include: time restriction (telling them to stop playing after a certain, non-clearly defined, time) and/or content restriction, establishing rules (only for a certain time, only at weekends), firm attitude against social pressure to buy certain games and 
acceptance by children of parental supervision (asking permission before playing). Over and above their concern over the early age at which children access devices and contents, which is becoming harder and harder for parents to control, some parents prefer to establish rules rather than impose restrictions, since they question the effectiveness of this latter strategy and stress the importance of children accepting parental control or supervision.

\begin{tabular}{|c|c|c|}
\hline \multicolumn{3}{|c|}{ Parental mediation strategies for playing video games } \\
\hline \multirow[t]{3}{*}{$\begin{array}{c}\text { Control } \\
\text { strategies }\end{array}$} & $\begin{array}{l}\text { Time } \\
\text { restriction } \\
\text { and } \\
\text { establishment } \\
\text { of rules }\end{array}$ & $\begin{array}{l}\text { "She has a Nintendo and a computer, and uses them only when we let } \\
\text { her, at weekends, because otherwise she'd be on them all day. I don't } \\
\text { think it's necessary to spend all day playing on the Nintendo. We keep } \\
\text { a close watch, and with You Tube too, because she also has access. } \\
\text { You hear so many things on the tele ... and you're there ... It scares } \\
\text { me." }\end{array}$ \\
\hline & $\begin{array}{l}\text { Content } \\
\text { restriction }\end{array}$ & $\begin{array}{l}\text { "We don't let the little one play San Andreas, which consists of hitting } \\
\text { prostitutes (via the Internet). Gaming platforms have come on a lot, } \\
\text { you have to buy a license. This was something we specifically forbade. } \\
\text { They don't understand it. You think you just go out and chase people. } \\
\text { We decided to just take it away from them." }\end{array}$ \\
\hline & $\begin{array}{l}\text { Establishing } \\
\text { rules and } \\
\text { parental } \\
\text { supervision }\end{array}$ & $\begin{array}{l}\text { "Can you forbid them to play it? I don't know. My } 14 \text {-year-old son has } \\
\text { it (Call of Duty) but then so do all his friends. The younger one is } \\
\text { worse. When my kids are at home alone they call me and say 'can we } \\
\text { turn the computer on?' They always ask permission." }\end{array}$ \\
\hline \multirow[t]{3}{*}{$\begin{array}{l}\text { Support } \\
\text { and } \\
\text { guidance } \\
\text { strategies }\end{array}$} & $\begin{array}{l}\text { Instructive } \\
\text { strategies }\end{array}$ & $\begin{array}{l}\text { "You have to set limits. I tell my daughters 'It's not good for your } \\
\text { health to be sitting there playing for so long.' If you don't establish } \\
\text { limits ... I told my youngest daughter that lots of Asians have to wear } \\
\text { glasses because they hardly ever go out." }\end{array}$ \\
\hline & & $\begin{array}{l}\text { "Take me for example ... when you asked how we taught them ... As } \\
\text { far as I'm aware, we didn't teach them at all ... I have absolutely no } \\
\text { idea how you play on the Xbox. They know ... ha ha ... and I pick up } \\
\text { their PSP and say 'how do you turn this thing off?' And the other day I } \\
\text { noticed something ... he was in his room... he'd been given an Xbox } \\
\text { game and he started playing the other day and couldn't do it ... and } \\
\text { he started getting angry. So I said to him 'first look and see how it's } \\
\text { played.' He just expected to start playing immediately, he wanted to } \\
\text { be able to do it straight away ... I think it's intuitive." } \\
\text { "If it's a game with lots of blood and killing, etc. I tell him he can } \\
\text { shoot, but that it's not how the real world works." }\end{array}$ \\
\hline & $\begin{array}{l}\text { Support for } \\
\text { self- } \\
\text { regulation }\end{array}$ & $\begin{array}{l}\text { "In our case, our kids do lots of extracurricular activities. We never } \\
\text { restrict the time they can spend playing video games because we don't } \\
\text { need to, because they spend so much time at school and then playing } \\
\text { sport. No matter how much time you try and give them, they can only } \\
\text { ever play for about half an hour a day." }\end{array}$ \\
\hline
\end{tabular}

Table. 3. Control and support-guidance strategies for mediating children's video gaming 
For their part, support-guidance strategies include instructive measures and advising children about use and informing them of the consequences. Here, parents provide their children with verbal guidelines in order to encourage a more reflexive and less intuitive type of use. They also point out the difference between reality and fiction. Another type of support strategy consists of organizing the child's extracurricular activities so as to foster self-regulation. It is striking that none of the parent groups mentioned co-playing strategies. Finally, a single permissive strategy was recorded "he knows the difference between right and wrong (in reference to playing violent video games)."

\section{d. Parents' perceived difficulties}

The difficulties perceived by parents in relation to mediating their children's video game playing center around uncontrollability and the digital divide. The first of these is usually associated with the early age at which children access games and social pressure (peers, friends and relatives), as evident in the comment made by this mother:

For example, I said 'he won't get his hands on a Nintendo until such and such an age', and then it turns out he borrowed a friend's one or his cousin's. His father says 'he hasn't got a clue' but he learned straight away how it works. He started playing long before I thought he would.

The following example also alludes to these same difficulties:

You go to 'Game' to buy games and you see all these violent video games for 15-16-year-olds and you buy them for him. And if you don't ... he just goes round a friend's house to play. He knows the difference between right and wrong. If it's a game with lots of blood and killing, etc. I tell him he can shoot, but that it's not how the real world works.

In this case, the boy's mother surrenders to social pressure, even though she knows that the games are inappropriate for her son's age due their violent content. She uses a combination of two types of strategies: a permissive one ("he knows the difference between right and wrong") and an instructive one ("I tell him he can shoot but that it's not how the real world works"). At other times, perceived uncontrollability is associated with the risks inherent in the Internet:

You have to be careful ... Now they've started wanting to play on-line games we've taken everything away: mobile data, $\mathrm{Wi}-\mathrm{Fi}$, because if you have everything ... It gets out of hand ... really. With my kids too ... the truth is it's all intuitive.

Finally, parents acknowledge that the rate at which their children develop media and digital competences is too fast for them (digital divide):

Yes, it's intuitive. I have a 4-year-old son and someone bought him an $80 €$ game and he can already play it. They're totally comfortable with it. He knows loads and he's only little ... people buy games for them and you don't even realize.

Along the same lines, another parent states "There's no doubt about it. They just pick it up and start playing straight away. I need some time to adapt, but they just get it immediately." Some parents even allude to the fact that they have made no effort at all to try to understand and learn to use video consoles. For example, "As far as I'm aware, we didn't teach them at all. I don't even know how he learned to use his PSP, it certainly wasn't from watching us. In this case no, I don't know how it works." One parent summed it up as follows "They live in a different environment from ours." 


\section{Discussion}

Parents provide different perceptions regarding their children's video gaming use. It seems that these differences are more noticeable in 6th grade than in 3rd grade, since boys connect up to the Internet more than girls, thereby gaining access to a wide variety of video games, including games targeted at older players with a clearly violent profile. Moreover, the data may confirm the lack of equality in both the offer available on the market and general perceptions regarding preferences and uses (Bertomeu, 2011; Zhao \& Linaza, 2015), since boys are associated with active, action-based roles, while girls' games are aimed at reproducing supposedly female roles (being a nurse, looking after a pet, etc.).

In relation to negative beliefs about their children's use of video games, parents are concerned about the early age at which children start playing games, possible risks and the negative psychological (e.g. risk of addiction), physical (e.g. health risks owing to excessive use) and/or social consequences (e.g. electronic play vs social play) resulting from excessive playing and the age-inappropriateness of the content (mainly due to the presence of violence). Parents also raised an as yet unanswered question that it might be interesting to explore: under what circumstances is playing video games associated with resting? Or do the interaction and activity involved prevent this? These worries have already been mentioned by Kutner et al. (2008) as parents' most pressing concerns, namely time spent playing and risk of eclipsing other academic and leisure activities; possible harmful psychological and physical effects; and mediation (should I forbid them or not?).

There can be no doubt that one of the things that most concerns parents is the phenomenon of on-line co-playing (with friends and/or strangers, forming groups, etc.), since children access the Internet at increasingly early ages and from different devices, which makes it harder for parents to regulate its use. Reig \& Vilchez (2013) point out that more direct personal relations may be being replaced by remote, technologically-mediated ones, but that these new "virtual" modes do not necessarily exclude those that take place in "real" space and time. Moreover, parents also tend to worry about children's relationships in the "real" world. According to the data collected in our study, both boys and girls play alone, but they also often play in the company of friends or siblings. These new modes of relating to and communicating with others may coexist with traditional ones; i.e. they are not mutually exclusive.

The data gathered in relation to mediation styles and strategies indicate that parents use more controlbased and restrictive strategies than general support-based or instructive ones, which consist of fostering communication (such as recommending children play video games in a more reflexive manner), although many use mixed mediation or a combination of different styles. Controlling the time for which children are allowed to play video games is the most commonly used strategy, but as the data collected from participants in both phases of the study confirm, and consistently with that found in other studies (aDeSe, 2009; Lenhart et al., 2008), parents are rarely involved in the games themselves. They talk about the negative consequences and dangers associated with their children's use of video games but do not mention whether or not it interferes with parent-child communication. In this sense, more research is needed in the field of electronic media, communication and family studies to explore the concepts of participatory learning (Clark, 2011) and distant mediation (Zaman et al., 2016) in more depth and analyze the processes and interactions that take place in the family unit in relation to video games. 
It has been found that parents tend to use reactive strategies (i.e. strategies with no prior planning, such as restricting playing time because they think their children have been on their consoles for too long, but without specifically establishing beforehand how long they can play for or the times of day at which playing is permitted) more than proactive ones, which are planned and agreed upon beforehand. Since parents generally do not play video games with their children, it is necessary to visualize positive experiences for joint participation. This is one of the aims that should be adopted by educational interventions (Steinberg, 2012), namely to encourage parents to gradually move towards more reflexive and proactive mediation.

No differences were observed in the mediation styles and strategies used in accordance with children's age or school year. Nevertheless, parents of 6th graders do tend to restrict their sons' video gaming more than their daughters', and tend also to co-play more with their male offspring than with their female ones. This finding is consistent with the fact that boys at this age play more video games than girls, and tend to do so more on-line. Other differences were also observed in relation to sex, with parents imposing timetables more often on their sons than on their daughters. Fathers are also more instructive with their children, and tend to explain to them more different aspects related to the functionality of video games and consoles. Moreover, fathers with daughters instruct and co-play with them more than fathers with sons. Does this reflect a more intense "protector role" of fathers in relation to their daughters? Mothers lean more towards restriction, and do so more with their sons than with their daughters. The reasons for this may be that boys play more video games, do so more frequently on the Internet and access more violent content. These aspects should be explored in more depth in the future.

Since negative beliefs can constitute a barrier to using video games for informal and formal learning, training actions should strive to disseminate successful experiences in order to involve parents more (Prensky, 2005) and foster the idea that playing video games is something they can do alongside their children, as a shared activity which has a positive effect on the media and digital literacy of both generations. Moreover, the progressive increase in the popularity of on-line gaming among children means that parents should make an effort to improve and strengthen communication and trust between them and their children, not only to enable them to deal effectively with their children's problems or difficulties, but also to dissipate negative conceptions and manage the use of video games in a more proactive manner.

There are some limitations to the current study that should be noted. First, although our intention was to know about our closest context, future research should expand the sample to generalize the data or to contrast with other contexts. Secondly, it is also necessary to expand the sample of parents because mothers in this research have participated more in the focus groups.

The results found have educational implications for gender socialization in the media and family environment, oriented towards fostering equality-based attitudes during this transition from childhood to adolescence, in response to the demands for more information and training expressed by families and ultimately aimed at identifying best practices in this field. 


\section{Acknowledgment}

This research was supported by the University of the Basque Country UPV/EHU [EHU13/65, UFI11/04, GIU15/14], the Ministry of Economy and Competitiveness of the Government of Spain and the European Social Fund [BES-2015-071923].

\section{References}

aDeSe (2009). Usos y hábitos de los videojugadores españoles. Retrieved from http://www.aevi.org.es/web/wpcontent/uploads/2015/12/anuario-memoria-2006.pdf

AEVI (2015). 15 Anuario de la industria del videojuego. Retrieved from http://www.aevi.org.es/web/wpcontent/uploads/2016/06/MEMORIA-ANUAL_2015_AEVI_-definitivo.pdf

Aierbe, A., \& Oregui, E. (2016). The values and emotions in children's audiovisual fictional narratives. Comunicar, 47(24), 69-77. doi: 10.3916/C47-2016-07

Bertomeu, M. A. (2011). Nativos digitales: una nueva generación que persiste en los sesgos de género. Revista de Estudios de Juventud, 92, 187-202. Retrieved from http://www.injuve.es/sites/default/files/RJ92-13.pdf

Bourgonjon, J., Valcke, M., Soetaert, R., Wever, B., \& Schellens, T. (2011). Parental acceptance of digital gamebased learning. Computer \& Education, 57(1), 1434-1444. doi: 10.1016/j.compedu.2010.12.012

Cánovas, G. (2005). Videojuegos, menores y responsabilidad de los padres. Madrid: Defensor del Menor, Protégeles y Civertice. Retrieved from http://ardilladigital.com/DOCUMENTOS/TECNOLOGIA\%20EDUCATIVA/TICs/T8\%20VIDEOJUEGOS/estudio_vi deojuegos.pdf

Clark, L. S. (2011). Parental Mediation Theory for the Digital Age. Communication Theory 21(4), 323-343. doi: 10.1111/j.1468-2885.2011.01391.x

Coyne, S. M., Padilla-Walker, L. M., Stockdale, L., \& Day, R. D. (2011). Game on...girls: Associations between coplaying video games and adolescent behavioral and family outcomes. Journal of Adolescent Health, 49(2), 160-165. doi: 10.1016/j.jadohealth.2010.11.249

DeCamp, W., \& Ferguson, C. J. (2017). The Impact of Degree of Exposure to Violent Video Games, Family Background, and Other Factors on Youth Violence. Journal of Youth and Adolescence, 46(2), 388-400. doi: 10.1007/s10964-016-0561-8

Kutner, L. A., Olson, C. K., Warner, D. E., \& Hertzog, S. M. (2008). Parents' and sons' perspectives on video game play. A qualitative study. Journal of Adolescent Research, 23(1), 76-96. doi: 10.1177/0743558407310721

Lenhart, A., Kahne, J., Middaugh, E., Macgill, A. R., Evans, C., \& Vitak, J. (2008). Teens, video games, and civics: Teens' gaming experiences are diverse and include significant social interaction and civic engagement. Washington, DC: Pew Internet \& American Life Project. Retrieved from https://eric.ed.gov/?id=ED525058

Livingstone, S., Marsh, J., Plowman, L., Ottovordemgentschenfelde, S., \& Fletcher-Watson, B. (2014). Young children (0-8) and digital technology. A qualitative exploratory study - National report - UK. Luxembourg: Joint Research Centre, European Commission. Retrieved from http://eprints.Ise.ac.uk/60799/

Lloret, D., Cabrera, V., \& Sanz, Y. (2013). Relaciones entre hábitos de uso de videojuegos, control parental y rendimiento escolar. European Journal of Investigation in Health, Psychology and Education, 3(3), $237-248$. doi: $10.1989 /$ ejihpe.v3i3.46

Martins, N., Matthews, N. L., \& Ratan, R. A. (2015). Playing by the Rules: Parental Mediation of Video Game Play. Journal of Family Issues, 38(9), 1215-1238. doi: 10.1177/0192513X15613822

Nikken, P., \& Jansz, J. (2006). Parental mediation of children's videogame playing: A comparison of the reports by parents and children. Learning, Media and Technology, 31(2), 181-202. doi: 10.1080/17439880600756803

Oosting, W., IJsselsteijn, W. A., \& de Kort, Y. A. W. (2008). Parental perceptions and mediation of children's digital game play at home: A qualitative study. Retrieved from http://citeseerx.ist.psu.edu/viewdoc/download?doi=10.1.1.483.1577\&rep=rep1\&type=pdf 
Oregui, E. (2018). Consumo mediático infantil, habilidades narrativas y percepción de valores/contravalores en dibujos animados. Donostia - San Sebastián: Universidad del País Vasco (UPV/EHU). Retrieved from http://hdl.handle.net/10810/32103

Prensky, M. (2005). Listen to the Natives. Educational Leadership, 63(4), 8-13. Retrieved from http://www.ascd.org/ASCD/pdf/journals/ed_lead/el200512_prensky.pdf

Punamäki, R. J., Wallenius, M., Hölttö, H., Nygard, C. H., \& Rimpelä, A. (2009). The associations between Information and Communication Technology (ICT) and peer and parent relations in early adolescence. International Journal of Behavioral Development, 33(6), 556-564. doi: 10.1177/0165025409343828

Reig, D., \& Vílchez, L. F. (2013). Los jóvenes en la era de la hiperconectividad: tendencias, claves y miradas. Madrid: Fundación Telefónica y Fundación Encuentro.

Sarabia, F. J., \& Muñoz, J. (2009). Actitud y mediación de la familia hacia la exposición a Internet de los niños y adolescentes. Un enfoque de marketing. Esic Market, 133, 161-189. Retrieved from http://www.esic.es/documentos/revistas/esicmk/090505_113838_E.pdf

Schafer, R. B., \& Tait, J. L. (1981). A guide for understanding attitudes and attitude change. Ames, Iowa: North Central Regional Extension Publication 138, Iowa State University.

Sheffield, A. (2014). Co-playing Video Games and Parent-Child Relationships. In M. Searson \& M. Ochoa (Eds.), Proceedings of Society for Information Technology \& Teacher Education International Conference 2014 (pp. 693-698). Chesapeake, VA: Association for the Advancement of Computing in Education (AACE) Retrieved from https://www.researchgate.net/publication/276921978_Coplaying_video_games_and_parent-child_relationships

Shin, W., \& Huh, J. (2011). Parental mediation of teenagers' video game playing: Antecedents and consequences. New Media \& Society 13(6), 945-962. doi: 10.1177/1461444810388025

Steinberg, S. (2012). The modern parent's guide to kids and video games. Lilburn, GA: P3 Power Play Publishing.

Wartella, E., \& Jennings, N. (2001). New Members of the Family: The Digital Revolution in the Home. Journal of Family Communication, 1(1), 59-69. doi: 10.1207/S15327698JFC0101_07

Zaman, B., Nouwen, M., Vanattenhoven, J., de Ferrerre, E., \& Van Looy, J. (2016). A Qualitative Inquiry into the Contextualized Parental Mediation Practices of Young Children's Digital Media Use at Home. Journal of Broadcasting \& Electronic Media, 60(1), 1-22. doi: 10.1080/08838151.2015.1127240

Zhao, Z., \& Linaza, J. L. (2015). La importancia de los videojuegos en el aprendizaje y el desarrollo de niños de temprana edad. Electronical Journal of Research in Educational Psychology, 13(2), 301-318. doi: 10.14204/ejrep.36.14018 